\title{
IGFBP7 Gene
}

National Cancer Institute

\section{Source}

National Cancer Institute. IGFBP7 Gene. NCI Thesaurus. Code C73532.

This gene may play a role in growth factor signal modulation and tumor suppression. 